\title{
Refleksyjne odbicie architektury \\ - synteza wody i dzieła architektonicznego
}

\section{Reflective image of architecture- synthesis of water and an architectural work}

\section{Streszczenie}

Ddkad architektura towarzyszy człowiekowi, woda ma poważny wpływ na jej charakter. Pomijajac budowle inżynierskie, w których miałyby już takie sity odbioru. To dzieki wodzie budowle czessto stają sie dziełami sztuki. Podkreśla ona wyjatkowość, tworzy, czesto ze świattem i cieniem, tajemniczość budynku. W Południowej Ameryce znaleźć można wiele przykładów, które popierają powyższą teze. Równiez $w$ Europie znajdujemy budowle oparte na podobnej zasadzie. Nie należy zapominac tutaj, iz wiekkszość przykkadów architel turze towarzyszy zielen, jednym razem znajdujac sie w środku zielonego ogrodu a innym gdy zieleń przenika się $z$ wnętrzem budynku.
Wszystkie one moga być inspiracja dla budynku zaprojektowanego w Krakowie przez MTWW Architekci. Woda podkreśla budowe Wszystkie one moga być inspiracja dla budynku zaprojektowanego w Krakowie przez MTWW Architekci. Woda podkreśla budowe
odbiciami i refleksami. Zieleń pojawia się w środku i na zewnątrz sprawiając, że użytkownicy przez cały czas otoczeni są przez naturę. Abstract

Since architecture accompanied people, water has a serious impact on its character. Apart from engineering buildings, in which water Thanks to water buildings often become works of art. It emphasizes uniqueness, creates, often with light and shadow, the mystery of the building. There are many examples in South America that support this thesis. We find buildings based on a similar principles in Europe. It should not be forgotten that most of the examples were designed together with greenery, sometimes being in the middle o a green garden, another ti. users surrounded by nature the whole way through.

Stowa kluczowe: Woda, architektura $\mathrm{w}$ zieleni, odbicie, projektowanie zrównow
Keywords: Water, architecture in greenery, water reflection, sustainable design

WPROWADZENIE

Od początku architektury woda miała ogromny wpływ na charakter budowli. Pomijając obiekty inżynierskie, w których jest ona głównym aktorem, w wielu przypadkach stanowi niezwykłe uzupełnienie budowli, które niejednokrotnie bez niej nie miałyby już takiej siły odbioru. To dzięki wodzie architektura często staje się dziełem sztuki. Podkreśla ona wyjątkowość, tworzy, często ze świattem i cieniem, tajemniczość budynku. W Ameryce Południowej znaleźć można wiele przykładów, które popierają powyższą tezę. Również w Europie znajdujemy

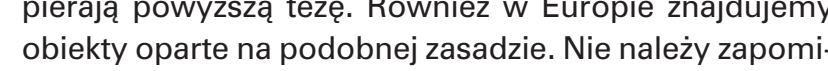
nać tutaj, iż większość przykładów przenika się w zieleni, jednym razem znajdując się w środku ogrodu a innym przenika się z wnętrzem. Wszystkie one mogą być inspiracją dla projektu budynku recepcyjnego w Krakowie autorstwa MTWW Architekci. Woda podkreśla architekturę odbiciami i refleksami. Zieleń pojawia się w środku

\section{INTRODUCTION}

Ever since the beginning of architecture, water has had an immense impact on the character of buildings. Apart from engineering structures in which it plays the leading role, in many cases it constitutes an extraordinary complementation to a building that would not leave the same impact without it. It is thanks to It highlights uniqueness, often facilitating a building's mysteriousness through light and shadow. In South America we can find many examples that support this thesis. In Europe we can also find structures based on similar principles. We should also not forget that in the majority of cases greenery also blends with them in one instance being located in the centre of a garden and in another blending in with the interior. All of them can be considered an inspiration for a design of a reception building in Krakow by MTWW Architekci. Water highlights architecture with reflec-
Ina zewnątrz sprawiając, że użytkownicy przez cały czas otoczeni są naturą.

Obecnośc wody w architekturze stała się jedną z głównych przyczyn rozwoju miast i polepszenia warunków życia ich mieszkańców. Nieustannie jest się dopełnieniem i wspołgra z architekturą i założeniami urbanistycznych. Idea basenów refleksyjnych, imitujących tafle lustrzana a także pełniących ważną role w zbilansowanym, zrównowazonym srodowisku siega odległych czasów starozytnych i tradycii budowania ogrodów perskich'. Woda zich gdzie podkreślała reprezentacyjność pałaców. Odbicie i fli zla wentem, a obecność fontann była niemal obowizkiem. Sieć nuwa obecniasc fon ieć tekturze. W czasach obenych liczba funkij wcaz se powiekza. Kolejne badai i wy hazk sp awiz

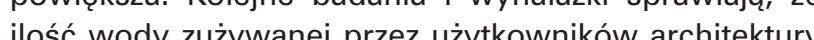
zaczyody zuzwanej przez uzytkownikow architektury

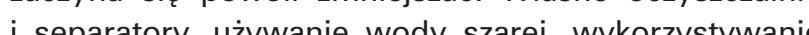
is separatory, uzywanie wody szarej, wykorzystywanie xx ixx I 作 basenami refleksyjnymi. Wprawdzie budowa prywatnych rezydencji wielkosci pałaców to juz rzadkosc, jednak woda pojawia się przy obiektach posiadających inne funkcje niż tylko mieszkalne. Budynki biurowe, rządowe hotele niejednokrotnie otoczone są basenami refleksynymi. Domy i rezydencje również posiadają niewielkie akweny odbijające otoczenie. Cześciej jednak pojawiaja się baseny służące relaksowi, najlepiej z widokiem i bez wyraźnej kraweedzi. Zacierają sie granice między woda a otaczającą ją przyrodą (infinity poo/s²)

Dokonując rzetelnej oceny basenów refleksyjnych i ich roli w dziele architektonicznym należy przeglądnąc ich najciekawsze przykłady z całego świata.

\section{TAJ MAHAL, INDIE}

Woda, stanowiła kluczowy element kompozycji ogrodów perskich, których doskonałym przykładem stało sie założenie Taj Mahal w Indiach. Jego budowa zakończyła sie w 1653 roku. Budynek świątyni ufundowany przez Shah Jahan i zaprojektowany przez architekta UstadAhmad Lahori stał sie jednym z najbardziej rozpoznawalnych obiektów na całym świecie i marzeniem wielu podróżników ${ }^{3}$. Jest uważany za najwiẹksze osiagniecie architektury islamu i Indii. Od ogromu symetrycznego założenia zajmującego prawie 17 hektarów ziemi, bujnych ogrodów, aż do najbardziej szczegółowych detali - jest obrazem nieśmiertelnej miłości, wyobrażeniem synonimem harmonit.

Gra swiatla i cieni, rytmów, symetrii tworzy niepowtarzany charakter miejsca. Niezwykłych rozmiarów centralny basen wodny zaprojektowany został tak, by stworzyc wrażenie głębokiej perspektywy i wspaniałego widoku na Mauzoleum Mumtaz Mahal. Powierzchnia wody jest spokojna i nieskazitelna. Skłaniać ma ona do refleks $j$, tions and mirror-like images. Greenery appears both inside and outside, causing the users to be constantly surrounded by nature.

The presence of water in architecture has become one of the main reasons behind the development of cities and the improvement of their residents' living conditions. It ceaselessly complements and harmonises with architecture and urban complexes. The conand that also pools that imitate a mirror surface cult and the tiviton of the building of Persian gadens. Water had become an insepara roque layouts, where it highlighted the representative character of palaces. Reflection in a mirror-like pool appeared to be their inseparable element, while the presence of fountains was almost mandatory. Melioration infrastructure, drinking water sources, values pertaining to aesthetics and relaxation-these are but a few of its meanings in architecture. In the present, this number of function increases further. Successive studies and inventions lead to the amount of water consumed by users of architecture is slowly starting to decrease. Individual separators and waste processing devices, the use of grey water or rainwater are but some of the few examples of caring about water.

The twentieth and twenty-first centuries have not end ed the period of highlighting buildings with reflective pize of par has ind appear near structures that feature other functions than residential stucs ings or hotels are often surrounded by reflective pools. Houses and residences also feature small pools that reflect the surroundings. However, pools used for relaxation, preferably with a view and no visible edge appear more often. They blur the line between water and the surrounding nature (infinity poo/s $s^{2}$.

When performing a comprehensive assessment of reflective pools and their role in a work of architecture, we should review their most interesting examples from all over the world.

\section{TAJ MAHAL, INDIA}

Water constituted the key element of the compositio of Persian gardens, an excellent example of which was the Taj Mahal complex in India. Its construction was compled in 1653. The temple building, commissioned by Shah Jahan and designed by the architect ognisable structures in the entire world and a dream sestintion for masy travellers ${ }^{3}$ It is consider to be the greatest achievement of Islamic and Indian architecture. From the sheer immensity of the symmetric complex, which occupies almost 17 hectares of land its lush gardens, to the finest of details-it is an image of immortal love, a synonym of harmony

The play of light and shadow, rhythms and symmetries, creates a unique character of the place. The complex's large central pool was designed to produce an appearance of a deep perspective and an ex- 


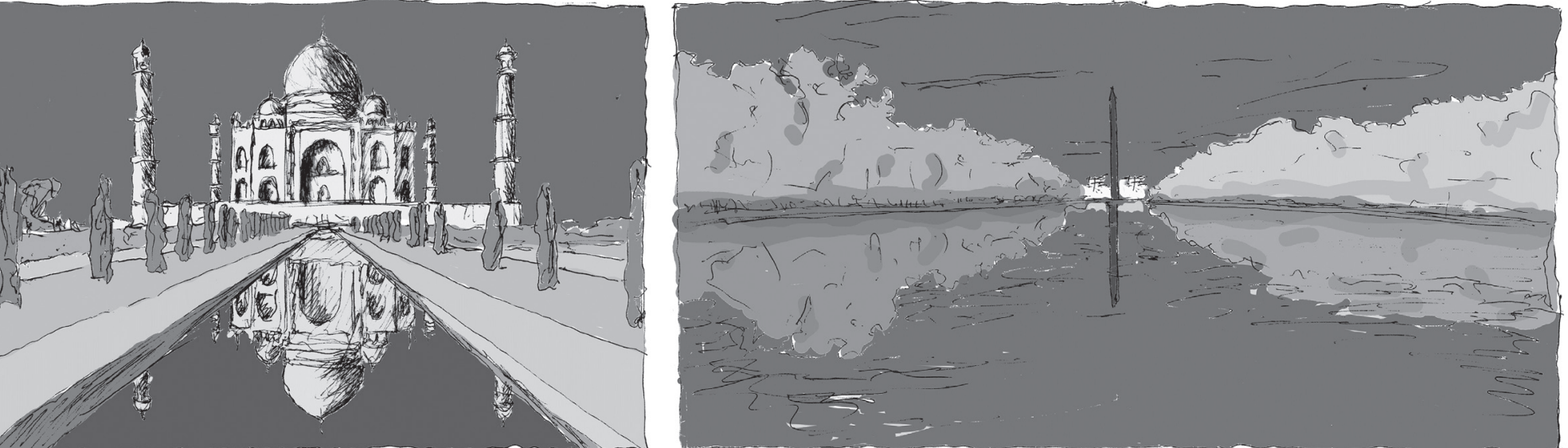

II. 1. Taj Machal, 1653, proj. Ustad-Ahmad Lahori, rys. Mariusz Twardowski / Taj Machal, 1653, designed by Ustad-Ahmad Lahori, drawing by Mariusz T Twardowski
II. L. Lincoln Memorial, 1924, proj. Henry Bacon, rys. Mariusz Twardowski / Lincoln Memorial, 1924, designed by Henry Bacon, drawing by Ma-
riusz Twardowski

zadumy, jest symbolem nieskończoności i podkreśla skalę założenia. Jest nieodłącznym elementem znanego w całym świecie widoku na swiątynię z jej idealnie odwzorowanym odbiciem w wodzie. Pełni ona także role systemu nawadniania ogrodów. Zbiornik wodny jes częścią założenia ogrodowego. Zatopiony w otoczeniu soczystej, uporządkowanej zieleni tworzy ramy perspektywiczne dla dzieła architektonicznego. Rankiem, nim turyści zdążą opanować teren, mauzoleum lśni w delikatnych promieniach wschodzącego słońca, a jego odbicie widoczne w zbiorniku urzeczywistnia to, czego nie potrafit dokonać żaden człowiek - tworzy doskonała kopie Światyni Miłości, niepowtarzalny obraz malowany przez połączenie natury i umiejętności rąk ludzkich ${ }^{5}$.

\section{BASEN REFLEKSYJNY LINCOLN MEMORIAL}

\section{WASZYNGTON, STANY ZJEDNOCZONE}

Miasto Waszyngton zaprojektowane przez Pierre Charlesa L'Enfanta zostało zbudowane na niezasiedlonym terenie niedaleko wschodniego wybrzeża Stanów Zjednoczonych. Idea wieloosiowego miasta barokowego w połączeniu z ortogonalną siatką ulic stworzyły urbanistykę nowej amerykańskiej stolicy. Szerokie aleje, ot warte przestrzenie, architektura przeplatająca się z obfita zielenią tworzą harmonijną kompozycję podkreślając wagę miasta na tle kraju. Ważne centrum rządowe zostato dodatkowo wyeksponowane i zaakcentowane dzięki masywnemu, geometrycznemu obeliskowi - pomnik Waszyngtona, który dumnie góruje nad okoliczną zabudową i terenami parkowym

Razem z powstałym później Lincoln Memorial i zlokalizowanym w sercu założenia, na osi placu basenem refleksyjnym stały się jednym z najbardziej rozpoznawalnych i symbolicznych miejsc w Stanach Zjednoczonych' ${ }^{7}$ Linearny akwen zaprojektowany został w 1924 roku przez Henrego Bacona. Ponad piętnaście milionów litrów wody staje się płótnem na którym nieustannie maluje się zmienny obraz otoczenia ${ }^{8}$. Niezwykły basen refleksyjny ing sun and its reflection, visible in the pool, realizes a combination of nature and the skill of human hands ${ }^{5}$. IGTON D.C., UNITED STATES OF AMERICA

The city of Washington, designed by Pierre Charles . Baroque city, combined with an orthogonal street grid, resulted in the urban layout of the new American capital. Its broad avenues and open spaces, as well as its architecture intertwining with lush greenery, create a harmonious composition, highlighting the significance of the city to the state. The importan government centre was further exposed and accentuated thanks to a massive, geometric obelisk-the Washington Monument, which proudly towers above the neighbouring buildings and park grounds ${ }^{6}$. tive pool placed at the heart of the complex, on the axis of the square, they have become some of the most recognisable and symbolic places in the United States of America?. The linear pool was designed in 1924 by Henry Bacon. Over fifteen million litres of water become a canvas upon which the constanty extraordinary reflective pool was a background for był them dla wielu wydarzeń w historii Stanów Zjednoczonych i wciąz bierze udzial w życiu miasta i kraju. Zlokalizowany pomiędzy Washington Monument, Lincol Memorial i National Mall z każdego miejsca umożliwi odwiedzajacym obserwacje niezwykłej dramatycznej scenerii. Niemal nieskończona, gładka powierzchnia wody roztacza sie we wszystkich kierunkach i stanow spektakularna podstawe dla pomników i zieleni. Po re konstrukcji w 2012 roku basen refleksyjny wykorzystuje system cyrkulacii wody która pobierana jest z pobliskiego zbiornika retercyinego Tidal Basin. Renowajiskiezolita zmiejszć jej wykorzystanie o ponad szescdziesiąt cztery miliony litrów każdego roku?

\section{MIASTECZKO SZTUKI INAUKI, WALENCJA, HISZPANIA} Hiszpańskie miasteczko Sztuki i Nauki (Ciudad de las Ares $y$ de as Ciencis) zosta zaprojktowad de las Ariago . tiago Calatravę. Architekt od najmłodszych lat poznawa Walencję, która jest jego rodzinnym miastem $10 . \mathrm{Z}$ jego obserwacji uwielbienia do swiatla powstal projekt kom pleksu zbudowany w latach 2005-2009 na trzydziestu pięciu hektarach"1. Zachwycą on swoją skalą i awangardową architekir. Za. Dywamika, geomatria, rytmicznoś symetria, rzeźbiarskość to jego główne cechy. Założenie znajduje się $\mathrm{w}$ połowie drogi pomiędzy miastem historycznym a wybzeżen Morza Balearkiego i staje się ich połączeniem. Składa się z Opery - Palau de les Arts, która zastąpiła planowaną na to miejsce wieżę telekomunikacyjną, Planetarium/kina - L'Hemisfèric, największego oceanarium Europy - L'Oceanogràfic, Muzeum Nauki - Museu de les Ciències Príncipe Felip, L'Umbracle oraz Agory. Miasteczko powstało na miejscu wyschnietego koryta rzeki Turia ${ }^{12}$. Architekt postanowil sprowadzic wodę $n$ many events in the history of the United States of the country. Located between the Washington Monument, the Lincoln Memorial and the National Mall, it provides visitors with the ability to observe the extraordinarily dramatic scenery from every place. The almost infinite, smooth surface of the water extends in all directions and constitutes a spectacular basis for monuments and greenery. After being remodelled in 2012, The renovion has made it posible to reluce water Thensumption by over sixty four million lites peryear.

CIUDAD DE LAS ARTES Y DE LAS CIENCIAS, VALENCIA, SPAIN

The Spanish City of Arts and Sciences (Ciudad de las Artes y de las Ciencias) was designed by Santiago Calatrava. The architect has been familiarising himself with Valencia ever since he was a child, as it is his hometown ${ }^{10}$. His observations and love of light produced a design of a complex built in the years 20052009 on thirty five hectares of land"1 It It impresses with its scale and avant-garde architecture. Dynamism, geometry, rhythm, symmetry and a sculptural character are its main characteristics. The complex is located half-way between the historical old town and the Balearic Sea coast and appears to be a link between them th is composed of an Opera House-Palau de les Arts. which replaced a tecommunications tower planned at the site, a Planetarium/cinemas- $-L^{\prime}$ Hemisferric, the ence Museum - Museu de les Ciències Príncipe Felip، 'Umbrocte as well as Agoras. The City was built at the site of that which no man ever could -it creates an excellen LINCOLN MEMORIAL REFLECTIVE POOL, WASHAlong with the later Lincoln Memorial and the reflec-

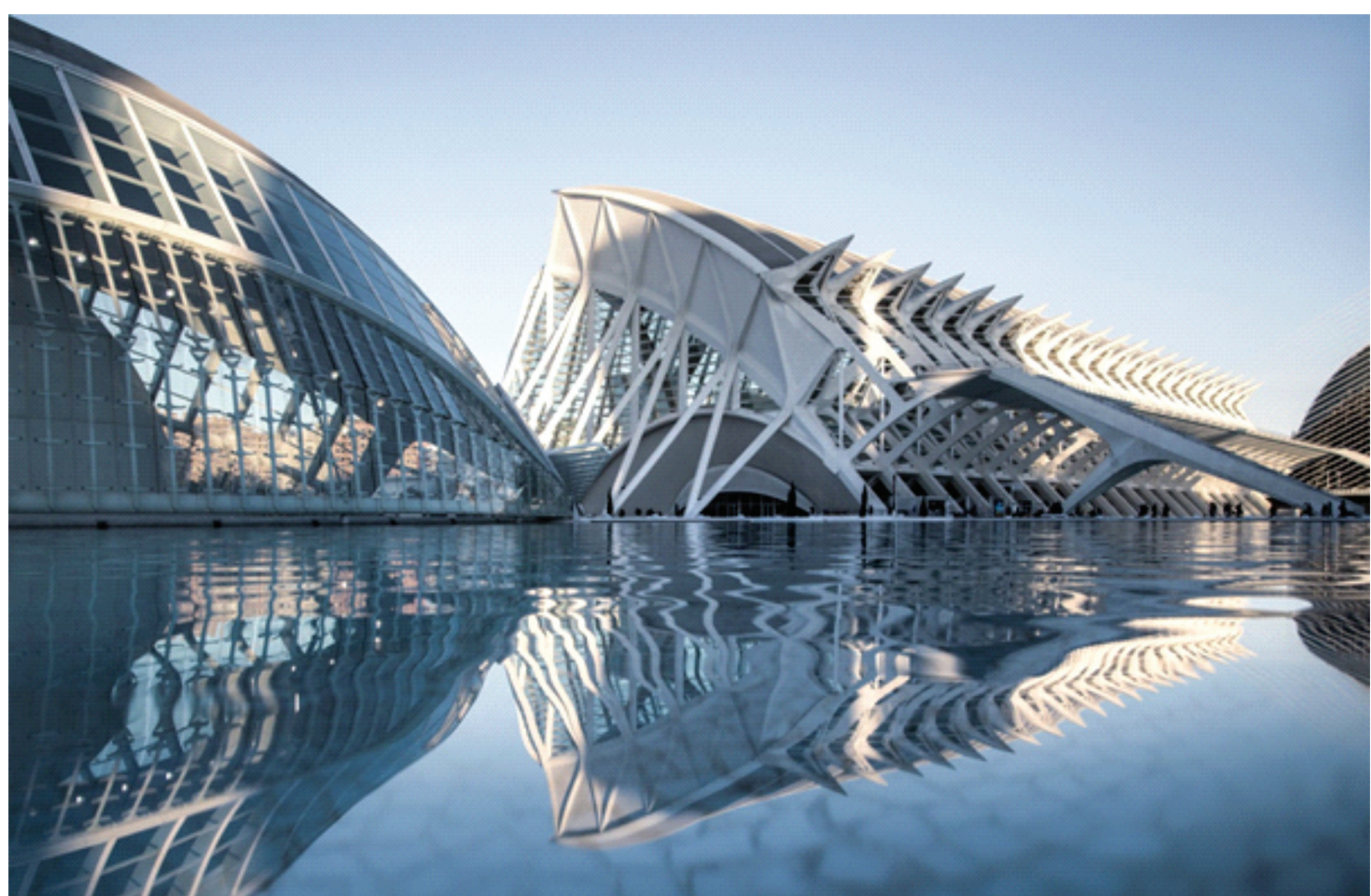


nowo do tego miejsca zatapiając otoczenie w płytkich ne biegnące z zachodu na wschód zdają się niemal wyrastać z otaczającej je wody, co podkreśla imponujący charakter kompleksu. Jasna kolorystyka, wykorzystanie odbijającej światto ceramiki na elewacjach i otaczająca budynki refleksyjna tafla sprawiaja, że całe założenie mieni sie $w$ promieniach słońca $w$ pogodne dni. Po zmroku miasteczko zdaje się być czécia przedstawiena teatralnego w którym główna role odgrywaja różnokolorowe światla táczạce $z$ architektura i pomnażane przez refleksjine bre (

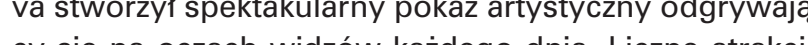
cy sie na oczach widzón każdego dnia. Liczne atrakcje zachęcaja nie tylk odw erajacych muzea, czy kno, ale

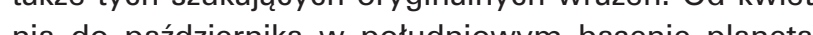
nia do pazdzienika w poludniowy basenie planetarium možna wypożyczyć rowerki wodne, kule, czy kajak $z$ przeżoczystym dnem i obserwowac budynki z niecodziennej perspektywy ${ }^{13}$. Wprowadza nowy wymiar do odczuw paia i postzegania architektury.

\section{PALÁCIO DO ITAMARATY, BRASILIA, BRAZYLIA}

Wspominając syntezę wody i dzieła architektonicznego nie sposob nie przytoczyc dzieł brazylijskiego architekta Oscara Niemeyera. Jest autorem najważniejszych budynków zlokalizowanych w jego rodzinnym kraju, zarówno tych rządowych, jak i obiektów kultury. Zatopiony w świecie krzywizn i łuków tworzył niecodzienne formy i kompozycje architektoniczne.

Praca Niemeya w Brasilii po wygraniu konkursu wraz z Lucio Costą w 1957 roku na nową stolicę Brazylii odcisnęła piętno na światowej architekturze modernizmu. Jedno z dziet, które tam stworzył wykracza poza jego dotychczasową utopiina wizje otaczajacego świata $a^{14}$. Tym znakomitym przyktadem brasilijkich budynków rzado-

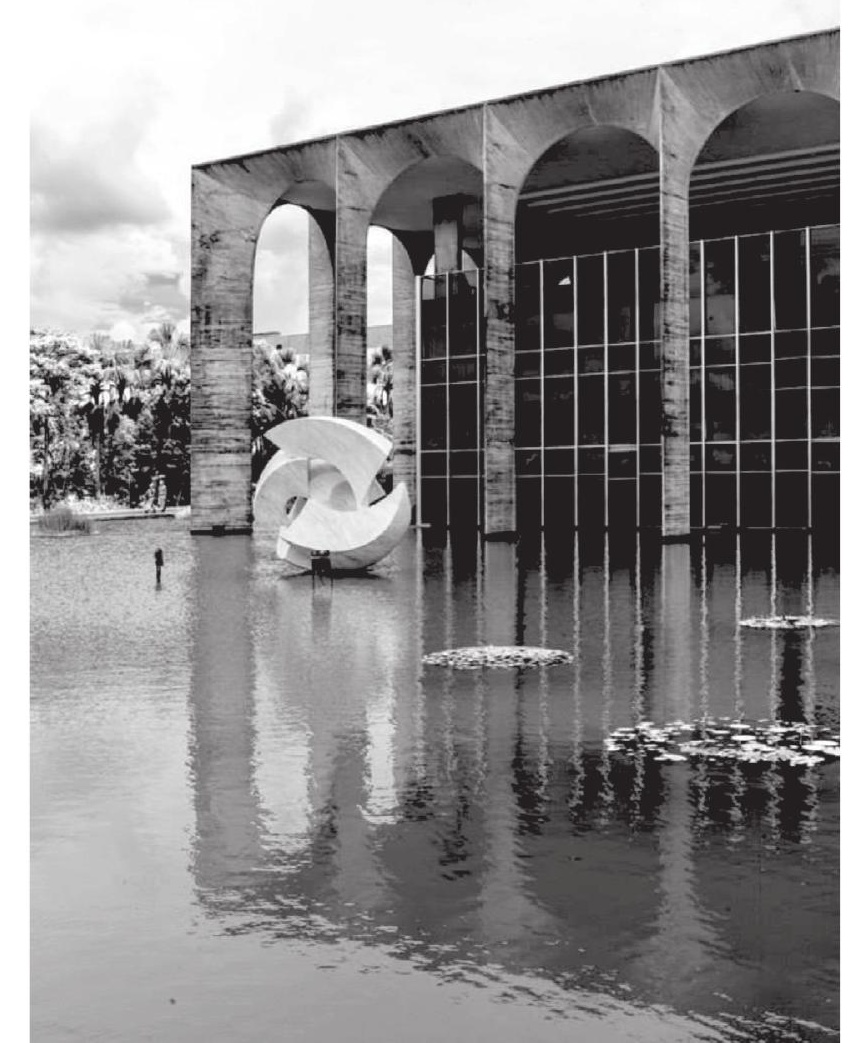

water to the site by building shallow pools in the surcomplex that runs along the east-west axis appear to almost grow out of the surrounding water, which highlights the impressive character of the layout. The bright colours, the use of reflective ceramic cladding on the facades and the reflective surface that surrounds the buildings causes the complex to shimmer in sunlight on sunny days. After dark, the City appears to be a part of a theatrical spectacle in which the main role is played by multi-coloured lights that fance with architecture and are multiplied by the re-

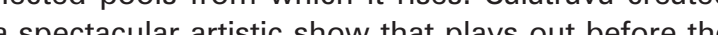
eyes of the audience every day. Numerous attractions entice not only those who visit the museums or the cinema but also those who search for origin experiences. Between April and October, the south ern pool of the planetarium offers the rental of wate bicycles, spheres and kayaks with a see-through botom which make it possible to observe the buildings from a different perspective ${ }^{13}$. It introduces a new dimension to experiencing and perceiving architecture.

PALÁCIO DO ITAMARATY, BRASILIA, BRAZIL

When discussing the synthesis of water and an architectural work, the works of the Brazilian architect Oscar Niemeyer are something that cannot be ignored. He is the author of the most important buildings located in his home country, includ ones and cultural facilities. Embedded in a world of curvatures and arches, he created unusual forms and

The work of Niemeyer in Brasilia after winning a competition along with Lucio Costa in 1957 for a new capital of Brazil has made its mark on world modernist architecture. One of the works that he had created there went beyond his previous utopian vision of the world

\section{4. Palácio Do Itamaraty, 1970, proj. Oscar Niemeyer, fot. Ma-
riusz Twardowski / Palácio Do Itamaraty, 1970, design by Oscar}

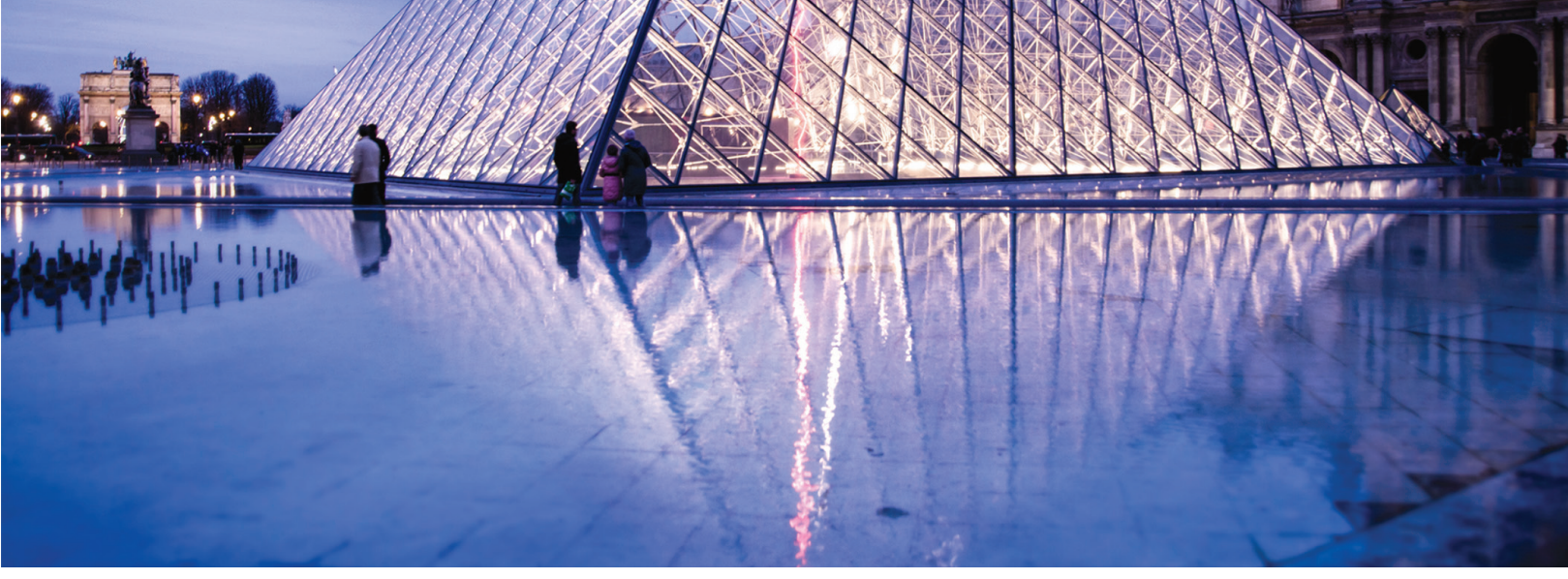

II. 5. Piramida Luwru, 1989, proj. leoh Ming Pei, fot. Agnieszka Żabicka / Louvre Pyramid 1989, designed by leoh Ming Pei, phot. by Agnieszka Żabicka

wych jest Palácio do Itamaraty. Obiekt mieści w sobie sedzibe Ministerstwa Spraw Zagranicznych. Nowoczesny pałac został otwarty w 1970 roku i po dziś dzień uznawany jest za jedno $z$ najznakomitszych dzieł architekta ${ }^{15}$ Jego symetria, rytm i niezwykła lekkość wynoszą obiek na wyższy poziom. Przed Pałacem Łuków zaprojektowany został basen refleksyjny, który okala budynek. Lustro wody podkreśla i umacnia wagę budynku. Piętnaście ostrych jak brzytwa kolumn każdej elewacji zdaje sie przecinać lustrzaną taflę z której wyrastaja. Niemal abstrakcyjny obraz który kształtuje architektura i jej odbicie staje się symbolem Brasilii, zaskakuje i wzrusza, skłania do refleksji, podkreśla powage miejsca' ${ }^{16}$

\section{PIRAMIDA LUWRU, PARYZ, FRANCJA}

W 1983 roku francuski prezydent Francois Mitterrand zlecit wykonanie projektu renowacji i reorganizacji Luwru amerykańskiemu architektowi chińskiego pochodzenia leoh Ming Pei. Po siedmiu latach od pierwzych szkiców można byto oglá nowy gtówny dziedzinc paryskiego muzeumin Monum wejści Mimo, że poczaktowo obca form gowego wejscia. Mino, ze począlkowo obca forma o szklanej

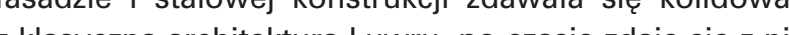
z klasyczna architek ku Luwn, po czasie zaje się z nia przenikac, stanowi jej nowoczesne dopehnienie, oddaje hołd historil. Stała się nieodłącznym elementem i ikona Paryża. Przejzyste piramidy zapewniają światło w pod ziemnej częsci muzeum. Wokô roztacza się lustrzan tafla wody, która potęguje wrażenie lekkości obiektu. W swojej niezmąconej wiatrem powierzchni odbija zarówno nowoczesność jak i historię. Łączy je w jedno dzieło architektoniczne. Tworzy nie tylko syntezę natury i architektury, ale także tradycji i innowacyjności. Rozcięcia w tafli wody zostały zaprojektowane jako przejścia zilian government buildings is Palácio do Itamaraty. The structure houses the Ministry of Foreign Affairs. sidered on of the architect's most excella an conside lightness elevate the building to the highest level front of the Palace of the Arches, a reflective pool was placed, surrounding the building. The water surface highlights and reinforces the building's significance. Fifteen razor-sharp columns on each facade appear to cut through the mirror-like surface from which they emerge. The almost abstract image that the architecture and its reflection produce becomes a symbol of Brasilia, surprising and eliciting emotion, evoking reflection, highlighting the solemnity of the place ${ }^{16}$.

\section{LOUVRE PYRAMID, PARIS, FRANCE}

In 1983 the French president Francois Mitterrand commissioned the Chinese-American architect leoh Ming Pei to prepare a design of the renovation and reorganisation of the Louvre. The new courtyard of the Parisian museum could be marvelled at seven years after the drawing of the first sketches ${ }^{17}$. A monumental pyramid constitutes the central dominant of the space and fulfils the role of a main entrance. De spite the fact that the initially alien form with a glazed facade and steel structure appeared to collide with Louvre's classical architecture, after some time now appears to blend in with it, constituting its mod ern complementation, being an homage to history. It has become an inseparable element and an icon of Paris. The see-through pyramids provide light to the underground part of the museum. A mirror-like water surface stretches around them, strengthening he impression of the structure's lightness. In its surand history It combines them into a single architectural work. It creates not only a synthesis of nature 

perspektywy. Kolejny raz woda stała się nieodłącznym elementem kompozycji podkreślającym rangę i funkcje obiektu.

\section{BUDYNEK RECEPCYJNY, KRAKOW, POLSKA}

Wszystkie opisane przykłady moga być inspiracja dla budynku zaprojektowanego w Krakowie przez MTWW Architekci . Woda podkreśla budowlę odbiciami i refleksami. Zieleń pojawia się w środku i na zewnątrz sprawiając, że użytkownicy przez cały czas otoczeni są natura. Na założenia kompozycyjne wpływ mają kształt działki, zapisy planu miejscowego (powierzchnia zabudowy, powierzchnia biologicznie czynna, wysokość budynku i linia zabudowy) $i$ założenia funkcjonalne. Zatem forma budynku przestała być przypadkowa. Tak różnorodne i skomplikowane założenia są pretekstem do "zabawy" w ksztattowanie bry.

Bryła pierwsza - biała, pojawia się po podniesieniu powierzchni fragmentu działki. Poderwany element podnosi się w górę tak, że powstaje tam biała forma w spadku zielonego dachu przeciwnym do spadku terenu. Na drodze „białej" bryły staje nieforemny „prostopadłościan" na rzucie trapezu, który dla poprawienia dynamiki minimalnie zostaje "ruszony" od pionu (o 3 ).

Bryła "biała” pokryta jest zielonym dachem. Jest kontynuacją ogrodu. Znalazła się tam ścieżka prowadząca bezpośrednio do pomieszczeń prywatnych (jakby zastygła lawa spływająca do ogrodowych ścieżek). W miejscu przełamania bryły i działki znalazł się basen refleksyjny. Elewacja pokryta jest białymi płytami elewacyjnymi. Szklany prostopadłościan przyjął $\mathrm{w}$ parterze formę trapezu. Jego dłuższe elewacje zostały odchylone dodatkowo na zewnatrz o kolejne $3^{\circ}$ Osłoniete sa delikatnymi, czarnymi tamaczami światta które z jednej strony chronia domowników przed zbyt duża i jościa stońca a z drugiej zapewnia prywatność i skryja przed widokiem przechodniów. and architecture, but also of tradition and innovation. as passages for visitors. They make it possible to view the courtyard from various points, looking from a new perspective each time. Once again water has become an inseparable element of a composition highlighting the rank and function of the building

\section{RECEPTION BUILDING, KRAKOW, POLAN}

All of the previously discussed examples can be considered an inspiration for a building designed in Krakow by MTWW Architekci. Water highlights the structure through reflections and glimmers. Green作 surrounded by nature at all times.

The compositional assumptions of the project were affected by the shape of the lot, the regulations of the local plan (building footprint, biologically active surfaces, building height and setback line), as well as functional assumptions. Thus, the form of the build"ing ceased to be random. Such varied and complichape of the massing The first shape-col

evating the surface of a white, appears after $\mathrm{e}-$ suspended element is lifted up so that a white form appears in the incline of a green roof, oriented in opposition to the slope of the terrain. An irregula "cuboid" with a trapezoid floor plan, "moved" slightly (by 3 degrees) to improve dynamism, stands in the way of the "white" shape.

The "white" shape is covered by a green roof. It is continuation of the garden. It features $a$ path that leads directly to private rooms (as if solidified lava that flows down towards garden paths). In the place of the break between the massing and the lot, $a$ rewettive pool has been placed. The facade is covered with white facade cladding. The glazed cuboid took on the form of a trapezoid at ground level. Its longer facades were addilonally rotated outwards by another three degrees. They are shielded by delicate residents from excessive sunlight while on the other
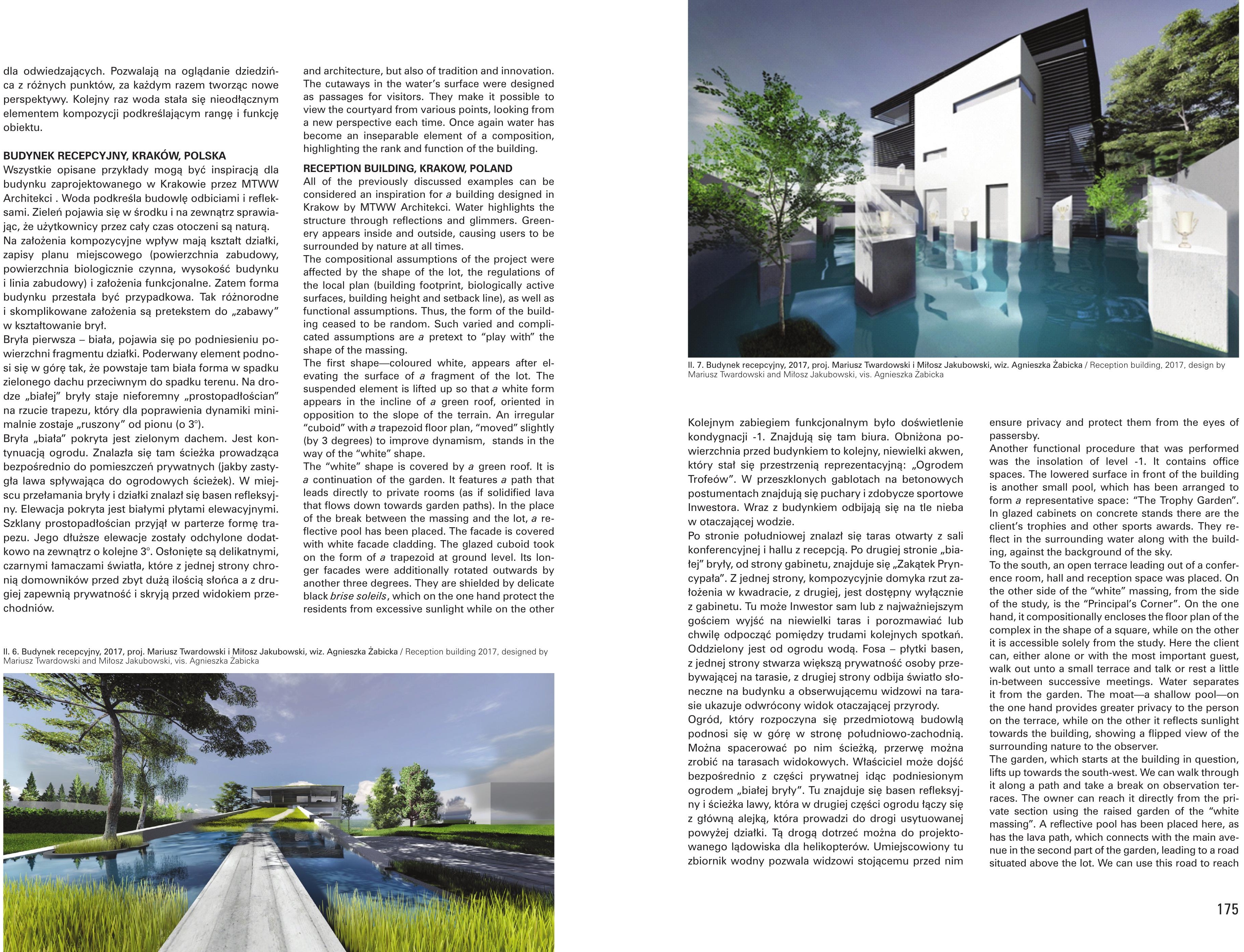

Kolejnym zabiegiem funkcjonalnym było doświetlenie kondygnacji -1. Znajdują się tam biura. Obniżona powierzchnia przed budynkiem to kolejny, niewielki akwen, który stał się przestrzenią reprezentacyjną: „Ogrodem Trofeów". W przeszklonych gablotach na betonowych postumentach znajdują się puchary i zdobycze sportowe Inwestora. Wraz z budynkiem odbijają się na tle nieba w otaczającej wodzie.

Po stronie południowej znalazł się taras otwarty z sali konferencyjnej i hallu z recepcja. Po drugiej stronie „biatej" bryły, od strony gabinetu, znajduje się „Zakattek Pryncypała". Z jednej strony, kompozycyjnie domyka rzut za tożenia w kwadracie, $z$ drugiej, jest dosteppny wyłącznie z gabinetu. Tu może Inwestor sam lub z naiważiejszym gościem wyjść na niewielki taras i porozmawiać lu chwile odpoczać pomiedzy trudami kolejnych spotkań Oddzielony jest od ogrodu woda. Fosa - plytki basen. z jednej strony stwarza wieksa prywatność osoby prezednej stony stwarza wieksza prywatnosc osoby przeby neczne na budynk a obsemuącenu widzowi na sie ukazuje odwroccony widok otaczającej przyrody. Ogró, który rozpoczyna się przedmiotową budowla podnosi się $\mathrm{W}$ gorę $\mathrm{W}$ stronę południowo-zachodnią. Można spacerowac po nim ścieżką, przerwę możn zrobić na tarasach widokowych. Whaściciel może dojśc bezpośrednio z części prywatnej idąc podniesionym ogrodem „biatej bryły”. Tu znajduje się basen refleksyj ny i ścieżka lawy, która w drugiej części ogrodu łączy sie z główną alejką, która prowadzi do drogi usytuowane powyżej działki. Tą drogą dotrzeć można do projektowanego lądowiska dla helikopterów. Umiejscowiony tu zbiornik wodny pozwala widzowi stojącemu przed nim ensure privacy and protect them from the eyes of passersby

Another functional procedure that was performed was the insolation of level -1 . It contains offic spaces. The lowered surace in front of the building

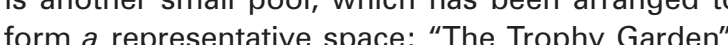
In glazed cabinets on concrete stands there are the client's trophies and other sports awards. They reflect in the surrounding water along with the building, against the background of the sky.

To the south an open terrace leading out of a conference room, hall and reception space was placed. On the other side of the "white" massing, from the side of the study, is the "Principal's Corner". On the one hand, it compositionally encloses the floor plan of the complex in the shape of a square, while on the other it is accessible solely from the study. Here the clien can, either alone or with the most important guest, walk out unto a small terrace and talk or rest a little in-between successive meetings. Water separates it from the garden. The moat-a shallow pool-on the one hand provides greater privacy to the person on towards the building, showing a flipped view of the The garding natre to the observer.

ding in question 作 races. The owner can reach it directly from the private section using the raised garden of the "white massing". A reflective pool has been placed here, as has the lava path, which connects with the main avenue in the second part of the garden, leading to a road situated above the lot. We can use this road to reach 
obserwować budynek, jego odbicie i horyzont z panoramą Krakowa.

Wnętrze budowli podzielone jest trójwymiarowo w poziomie i w pionie. Na parterze znajduje się duży hol z recepcją, który prowadzi do głównej sali konferencyjne (dzięki spadkowi dachu białej bryły jest ona nieco wyższa niż pozostałe powierzchnie, istnieje możliwość rozbudowy sali o kolejne pomieszczenia koktajlowe" i magazy nowe), mniejszej sali konferencyjnej i do gabinetu. Re prezentacyiny, wysoki na 5 metra jobicet stúćc bedzie prezentac do przyjmown 4,5 metra gabinet stużyc będzie

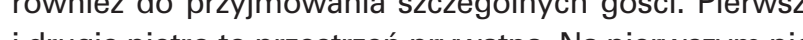
trug zne piętro to prźe

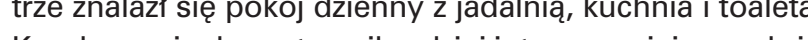

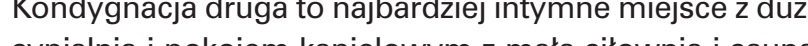
sypialnią i pokojem kapielowym z malą silownią i sauna. Tu, mozna zlapać oddech, odpoczac, nacieszyć się widokiem zieleni Zwierzynca w stronę poludniowo-zachodnia i widokiem Krakowa w stronę połnocno-wschodnią. $\mathrm{Na}$ dachu nad trójwymiarową klatką schodową znajduje sie

$\mathrm{Na}$ kondygnacjach parteru i pierwszego piętra znajduja się miejsca do prezentacji trofeów sportowych. Zaprac miejsca do prezentacji trofeów sportowych. Zailość puchán sposob prezentacji sprawia, ze ogromna losc pucharów, medali, pater, numerów rejestracyjnych, numerow startowych i innych nagród, z jednej strony
uwypuklona, $z$ drugiej, wpasowana we wnetrze budowli tak, by nie by

W budynku znajdują się jeszcze dwie kondygnacje. W częściowo podziemnej lecz doświetlonej dziennym światłem kondygnacji znajdują się biura (i w cześci niedoświetlonej robocze sale konferencyjne i magazyny). Na najniższej kondygnacji podziemnej znajduje sie garaż na 11 miejsc postojowych z pomieszczeniami technicznymi i kottownia.

Kompozycja zabudowy na działce sprawia wrażenie eleganckiej i trójwymiarowaj, gdzie bryty się przenikaja ele pompicieja a pósietlonej świ dzielonym od otoczenia w miejscach, które muszą pozostać bardziej prywatne czy nawet intymne.

Baseny refleksyjne wokół tego budynku spełniają ważBaseny refleksye wokó tego budy ku spelniaja wazsamego budynku, prezentowanych trofeów. Podkreślają trójwymiarowe rozwiązania rzeźbiarskie budynku. Jeden $z$ basenów domyka wewnętrzny taras uwypuklając znajdującą sie tam prywatność.

\section{PODSUMOWANIE}

Woda była i jest obecna w życiu człowieka. Bez niej nie byłoby ludzkości. Mimo, że jej obecność jest dla nas codziennością to jej niezwykła forma w postaci basenów refleksyjnych odgrywa wazną rolę $w$ kształtowaniu otoczenia i architektury. Refleksyjne odbicie w nieskazitenej lustrzanej tafli wody podkresla rangę budynkow oraz powagę znajdujących się w ich wnętrzu funkcji. Pomaga w zrównoważonym projektowaniu budynków oraz środowiska. Staje się elementem kompozycji. Dobrymi a newly-designed helicopter landing pad. A water who stands before it to tion and the horizon with a panorama of Krakow. The interior of the building is three-dimensionally $\mathrm{d}$ vided both horizontally and vertically. The ground floo features a large hall and reception, which leads to the main conference hall (thanks to the roof incline of the white massing it is slightly taller than the remaining surfaces, with an option to expand the hall through the addilon of addilonal "cocktail" and storage spaces), tative, 4,5 metres-high study can also be used to host the most important guests. The first and second floo is a private space. The first floor features a living room with a dining section, a kitchen and a toilet. The second storey is a more intimate place with a large bedroom, bathing room and a small gym and sauna. Here we can catch our breath, rest and enjoy the view of the greenery of Zwierzyniec towards the south-west and a view of Krakow towards the north-east. On the roof above a three-dimensional stairwell, there is a skylight which provides additional light.

The ground and first floor feature places for the presentation of sports trophies. The manner of presentation that was proposed causes the immense amoun of cups, medals, plaques, license plates, starting numbers and orher awards to, on the one hand, be highlighted, while placed in the interior of the building so as not to appear too overt for viewers on the other. The partially underground, yet insolated floor fea tures office spaces (with working confer tho reaand storage spaces). The lowest underground storey features a garage with 11 parking spaces, technical spaces and a boiler room

The composition of buildings on the lot appears elegant and three-dimensional, where massings intersect and rooms meander between storeys, bein well insolated where needed and separated from the surroundings in places that ought to remain private or even intimate.

Reflective pools around this building play an important aesthetic and representative role. They elevate the rank of the building itsell, as well as that of the presented trophies. They highight the three-dimensional and sculpture-like solutions of the buildings. One of the pools encloses the external terrace stressing its privacy.

\section{CONCLUSION}

Water was and still is present in man's life. Without it there would be no humanity. Despite its presence being considered a part of our daily reality, its extraordinary form expressed in reflective pools plays an important role in shaping our surroundings and architecture. A reflected image in the undisturbed mirror-like surface of water highlights the rank of buildings and the significance of the functions located within. It aids in the sustainable design of buildings and the environings designed by Oscar Niemeyer in Brazil (Palácio do przykładami mogą tu być budowle projektowane przez wejście do muzeum w Luwrze w Paryżu projektu leo Ming Peia. Basen refleksyjny Lincoln Memorial zaprojektowany przez Henriego Bacona podkreśla skalę i ważność otaczających go pomników, które upamiętniaja prezydentów Stanów Zjednoczonych, a także jest dopet nieniem terenów zielonych National Mall. Wyjątkowym przykładem stało sie również Miasteczko Sztuki i Nauki Santiago Calatravy, które w całości kszattuje sie jau wyspa oczona bak wie bytaby tak majestatycza, tak monum architekture fleksinośc wody, ḱtra przy odpowednich warunkach . twory doskony odbicie rzeczywistości zaciera granice mięzy nutu, a architektur. Thorzy synteze dziela czlowiek i prayody tak dobre widocz wa wiedoscignionych ogredach perskich Taj Mahal. Woda podnosi wartosci estetyczne i ma nieoceniony wpływ na charak ter budowli stanowiąc jej dopełnienie.

PRZYPISY

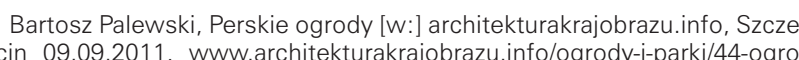

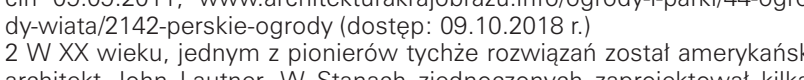

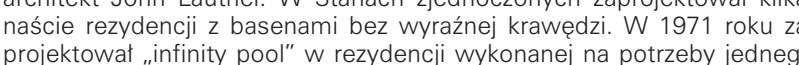

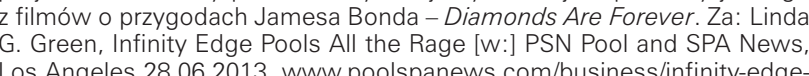
Los Angeles 28.06 .2013 , www.poolspanews
pools-all-the-rage o o (dostep: 29.10 .2018 r.)

pools-all-the-rage o o dostepp: 29.10.2018 r.)
3 Megan Sveiven-AD Classics: Taj Mahal / Shah Jahan [W:] Arch Daily
Sao Paulo 02.01.2011, www.archdaily.com/100528/ad-classilcs-taj-mahal shah-jahan (dostep: 09.10.2018 r.). 4 Taj Mahal
09.10 .2018 r. The Taj Mahal [w:] National Geographic Des Moines 21.02.2018, 09.10 .2018 r.)

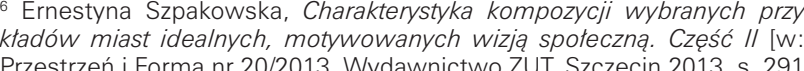

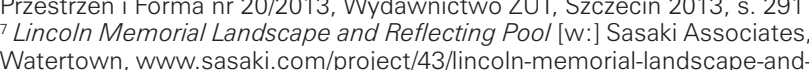

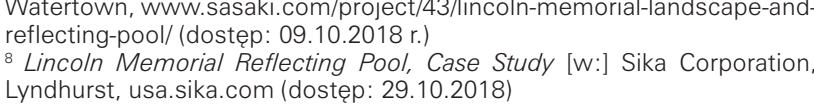
Lincoln Memorial Reffectitis Pool I Washington, DC, US [w:] Louis Berg

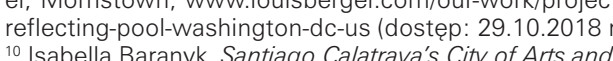

"Isabella Baranyk, Santago Calatrava's City of Arts and Sciences Through 09.04.2017, whw.archdaily-com/868774/santiago-calatravas-city-of-arts-
and-sciences-through-the-lens-of-photographer-sebastian-weiss (dostęp and-Sciences-through-the-lens-of-photographer-sebastian-weiss (dostete
09.10 .218 .

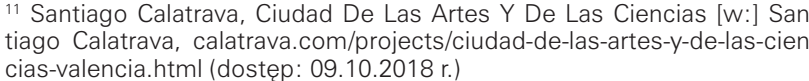

3. Disfruta este verano de las barcas, kayaks, water bikes y bolas en el lago
sur del Hemisferic [W:] ValenciaBonita.es, Walencia 08.03 2017 maws valenciabonita.es/2017/03/03/disfruta-este-verano-de-las-barcas-kayaks
water-bikes-y-bolas-en-el-lago-sur-del-hemisferic// dostep: 09.10 .2018 r.

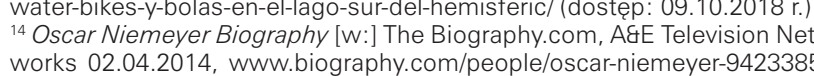

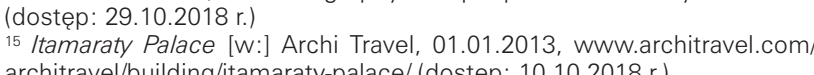

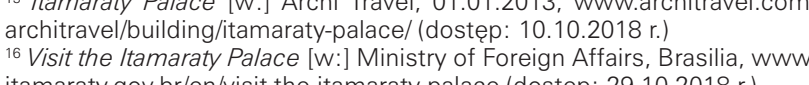

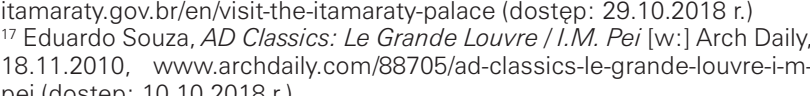

Itamaraty) or the entrance to the Louvre Museum in of this. The reflective pool of the Lincoln Memorial, designed by Henry Bacon, highlights the scale an importance of the monuments that surround it and which commemorate the presidents of the United States, in addition to being a complementing element of the green areas of the National Mall. The City of Arts and like an istand surrounded by pools filled with wed Without it the complex's architecture would not we majestic or as monumental as it is The reflectivity of water, which, under specific conditions, creates a perfect reflection of reality, blurs the line between nature and architecture. It creates a synthesis of the work of man and nature, so clearly visible in the unparaleled Persian gardens of Taj Mahal. Water increase aesthetic value and has an invaluable impact on the character of buildings, complementing them.

ENDNOTES

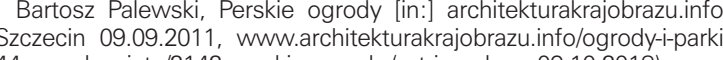
The American architect John Lautner became one of the of these solutions in the twentieth century. He designed aroun
a dozen residences with pools without a clear bordder in the United States. In 1971 he designed an "infinity pool" " built for the purposes
of a James Bond movie - Diamonds Are Frever. From: Lind
$G$ Green Intinty Edge Pools All the Rage lin:l PSN Pool and SPA G. Green, Infinity Edge Pools All the Rage lin: PSN Pool and SPA
News, Los Angeles 28.06.2013, ww. woolspanews.com/bus-

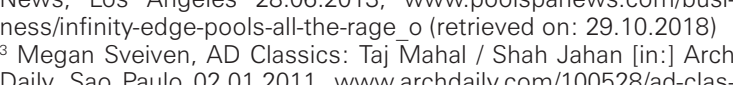
sics-taj-mahal-shah-jahan (retrieved on: 09.10.2018 Taj Mahal /in: Unesco.org Paryż, whc.unesco.org/en/list/252 (re-

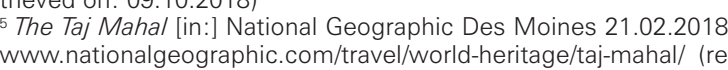

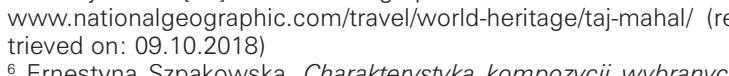
6Ernestyna Sizpakowska, Charakternstyka kompozycji wybranych
6 przyktadow miast idealnych, motywowanych wizia spoteczna

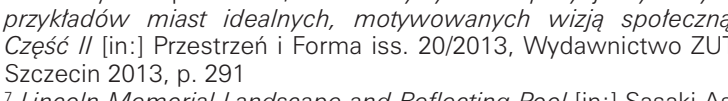
7. Lincoll Memorial Landscape and Reflecting Pool lin:] Sasaki As-
sociates, Watertown, www.sasaki.com/project/43/lincoln-memo Lincoln Memorial Reflecting Pool, Case Study lin:] Sika Corpora

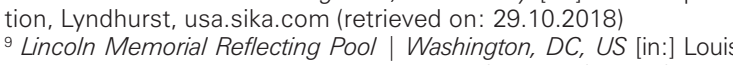

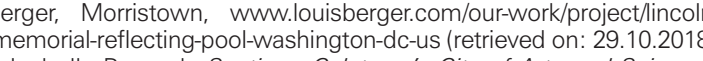

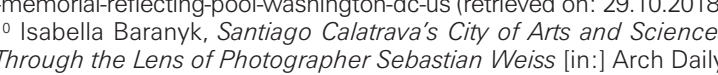
Sao Paulo 09.04.2017, www warchdaily.com/868774/santiago-cala
travas-city-of-arts-and-sciences-through-the-lens-of-photographer -sebastian--weiss S (retrieved on: 09.10.2018)
"I Santiago Calatrava, Ciudad De Las Artes Y De Las Ciencias [in:

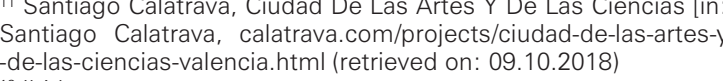

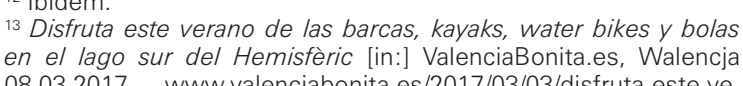
en el lago sur del Hemisferric [in: Valenciabonita.es, Walencj
08.03 .2017 , www valenciabonita.es/2017/03/03/disfruta-este-ve-

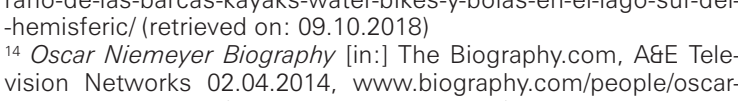
vision Networks 02.04.2014, www.biography.com/people/oscar
-niemeyer-9423385 (retrieved on: 29.10 .2018 ) -niemeyer-9423385 (retrieved on: 29.10.2018)
15 /tamarath Palace lin: Archi Travel, 0.101 .2013 , www.archi-
travel.com/architravel/building/itamaraty-palace/ (retrieved on

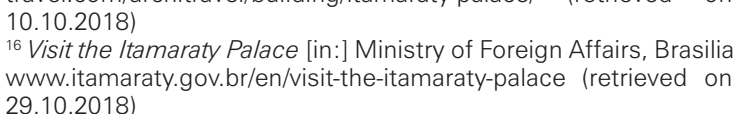




\section{LITERATURA}

[1] Baranyk, I., Santiago Calatrava's City of Arts and Sciences Through the Lens of Photographer Sebastian Weiss [w:] Arch Daily, Sao Paulo 09.04.2017, www.archdaily.com/868774/santiago-calatravas-city-of-arts-and-sciences-through-the-lens-of-photographer-sebastian-weiss

[2] Calatrava, S., Ciudad De Las Artes Y De Las Ciencias [w:] Santiago Calatrava,calatrava.com/projects/ciudad-de-las-artes-y-de-las-ciencias-valencia.html (dostęp: 09.10.2018)

[3] Disfruta este verano de las barcas, kayaks, water bikes y bolas en el lago sur del Hemisfèric [w:] ValenciaBonita.es, Walencja 08.03.2017, www.valenciabonita.es/2017/03/03/disfruta-este-verano-de-las-barcas-kayaks-water-bikes-y-bolas-en-el-lago-sur-del-hemisferic/ (dostęp: 09.10.2018 r.)

[4] Itamaraty Palace [w:] Archi Travel, 01.01.2013, www.architravel. com/architravel/building/itamaraty-palace/(dostęp: 10.10 .2018 r.) [5] Jagiełło-Kowalczyk, M., Przestrzeń kształtowana wodą - robinsonada [w:] Środowisko Mieszkaniowe $=$ Housing Environment, Wydawnictwo Politechniki Krakowskiej, Kraków 2012

[6] Lincoln Memorial Landscape and Reflecting Pool [w:] Sasaki Associates, Watertown, www.sasaki.com/project/43/lincoln-memorial-landscape-and-reflecting-pool/

[7] Lincoln Memorial Reflecting Pool | Washington, DC, US [w: Louis Berger, Morristown, www.louisberger.com/our-work/project/lincoln-memorial-reflecting-pool-washington-dc-us

[8] Lincoln Memorial Reflecting Pool, Case Study [w:] Sika Corporation, Lyndhurst, usa.sika.com

[9] Oscar Niemeyer Biography [w:] The Biography.com, A\&E Television Networks 02.04.2014, www.biography.com/people/oscar-niemeyer-9423385 (dostęp: 29.10.2018 r.)

[10] Palewski, B., Perskie ogrody [w:] architekturakrajobrazu.info, Szczecin 09.09.2011, www.architekturakrajobrazu.info/ogrody-i-parki/44-ogrody-wiata/2142-perskie-ogrody,

[11] Souza, E., AD Classics: Le Grande Louvre / I.M. Pei [w:] Arch Daily, 18.11.2010, www.archdaily.com/88705/ad-classics-le-grande-louvre-i-m-pei (dostęp: 10.10 .2018 r.)

[12] Sveiven, M., AD Classics: Taj Mahal / Shah Jahan [w:] Arch Daily, Sao Paulo 02.01.2011, www.archdaily.com/100528/ad-classics-taj-mahal-shah-jahan

[13] Szpakowska E., Charakterystyka kompozycji wybranych przykładów miast idealnych, motywowanych wizja społeczna. Część II, [w:] Przestrzeń i

Forma nr 20/2013, Wydawnictwo ZUT, Szczecin 2013

[14] Taj Mahal [w:] Unesco.org Paryż, whc.unesco.org/en/list/252

[15] The Taj Mahal [w:] National Geographic Des Moines 21.02.2018, www.nationalgeographic.com/travel/world-heritage/ taj-mahal/

[16] Visit the Itamaraty Palace [w:] Ministry of Foreign Affairs, Brasilia, www.itamaraty.gov.br/en/visit-the-itamaraty-palace (dostęp: 29.10.2018 r.)
17 Eduardo Souza, AD Classics: Le Grande Louvre / I.M. Pei [in:] Arch Daily, 18.11.2010, www.archdaily.com/88705/ad-classics-le-grande-louvre-i-m-pei (retrieved on: 10.10.2018)

\section{BIBLIOGRAPHY}

[1] Baranyk, I., Santiago Calatrava's City of Arts and Sciences Through the Lens of Photographer Sebastian Weiss [w:] Arch Daily, Sao Paulo 09.04.2017, www.archdaily.com/868774/santiago-calatravas-city-of-arts-and-sciences-through-the-lens-of-photographer-sebastian-weiss

2] Calatrava, S., Ciudad De Las Artes Y De Las Ciencias [w:] Santiago Calatrava,calatrava.com/projects/ciudad-de-las-artes-y-de-las-ciencias-valencia.html (dostęp: 09.10.2018)

[3] Disfruta este verano de las barcas, kayaks, water bikes y bolas en el lago sur del Hemisfèric [w:] ValenciaBonita.es, Walencja 08.03.2017, www. valenciabonita.es/2017/03/03/disfruta-este-verano-de-las-barcas-kayaks-water-bikes-y-bolas-en-el-lago-sur-del-hemisferic/ (dostęp: 09.10.2018 r.)

[4] Itamaraty Palace [w:] Archi Travel, 01.01.2013, www.architravel.com/architravel/building/itamaraty-palace/ (dostep: 10.10.2018 r.)

[5] Jagiełło-Kowalczyk, M., Przestrzeń kształtowana wodą - robinsonada [w: Środowisko Mieszkaniowe = Housing Environment, Wydawnictwo Politechniki Krakowskiej, Kraków 2012

[6] Lincoln Memorial Landscape and Reflecting Pool [w:] Sasaki Associates, Watertown, www.sasaki.com/project/43/lincoln-memorial-landscape-and-reflecting-pool/

[7] Lincoln Memorial Reflecting Pool | Washington, DC, US [w:] Louis Berger, Morristown, www.louisberger.com/our-work/project/lincoln-memorial-reflecting-pool-washington-dc-us

[8] Lincoln Memorial Reflecting Pool, Case Study [w:] Sika Corporation, Lyndhurst, usa.sika.com

[9] Oscar Niemeyer Biography [w:] The Biography.com, A\&E Television Networks 02.04.2014, www.biography.com/people/oscar-niemeyer-9423385 (dostęp: 29.10.2018 r.)

[10] Palewski, B., Perskie ogrody [w:] architekturakrajobrazu.info, Szczecin 09.09.2011, www.architekturakrajobrazu.info/ogrody-i-parki/44-ogrody-wiata/2142-perskie-ogrody,

[11] Souza, E., AD Classics: Le Grande Louvre / I.M. Pei [w:] Arch Daily, 18.11.2010, www.archdaily.com/88705/ad-classics-le-grande-louvre-i-m-pei (dostęp: 10.10.2018 r.)

[12] Sveiven, M., AD Classics: Taj Mahal / Shah Jahan [w:] Arch Daily, Sao Paulo 02.01.2011, www.archdaily.com/100528/ad-classics-taj-mahal-shah-jahan

[13] Szpakowska E., Charakterystyka kompozycji wybranych przykładów miast idealnych, motywowanych wizja społeczną. Cześć II, [w:] Przestrzeń i Forma nr 20/2013, Wydawnictwo ZUT, Szczecin 2013

[14] Taj Mahal [w:] Unesco.org Paryż, whc.unesco.org/en/list/252

[15] The Taj Mahal [w:] National Geographic Des Moines 21.02.2018, www. nationalgeographic.com/travel/world-heritage/taj-mahal/

[16] Visit the Itamaraty Palace [w:] Ministry of Foreign Affairs, Brasilia, www. itamaraty.gov.br/en/visit-the-itamaraty-palace (dostęp: 29.10.2018 r.) 